which results in accumulation of intracellular fat. The liver fat in Reye's syndrome is presumably caused by a temporary dysfunction in mitochondrial $\beta$-oxidation. It seems reasonable to assume that cases of sudden infant death with such fatty changes also have abnormalities of fatty acid $\beta$-oxidation, whether congenital or acquired.

Implicit in the currently accepted definition of the sudden infant death syndrome is that necropsy must be thorough to exclude adequate causes of death. ${ }^{20}$ Our findings indicate that all such investigations must include histological examination of the liver, and those livers showing diffuse panlobular fatty change should be further subjected to thorough histochemical and biochemical analysis of the state of mitochondrial enzymes. Conversely, the diagnosis of Reye's syndrome cannot be confirmed by the characteristic liver fatty infiltration without tests for mitochondrial enzyme activity (table II).

TABLE II-Histochemical and biochemical activity of mitochondrial enzymes in Reye's syndrome, medium chain acyl-coenzyme $A$ dehydrogenase deficiency, and sudden infant death syndrome, showing diffuse fatty change of liver

\begin{tabular}{lccc}
\hline \multicolumn{1}{c}{$\begin{array}{c}\text { Enzyme } \\
\text { activities }\end{array}$} & $\begin{array}{c}\text { Reye's } \\
\text { syndrome }\end{array}$ & $\begin{array}{c}\text { Medium change } \\
\text { acyl-coenzyme A } \\
\text { dehydrogenase } \\
\text { deficiency }\end{array}$ & $\begin{array}{c}\text { Fatty change } \\
\text { in sudden } \\
\text { infant death } \\
\text { syndrome* }\end{array}$ \\
\hline $\begin{array}{l}\text { Cytochrome oxidase } \\
\begin{array}{l}\text { Succinate dehydrogenase } \\
\text { Glutamate dehydrogenase }\end{array}\end{array}$ & $\downarrow \downarrow$ & $\begin{array}{c}\text { Normal } \\
\text { Normal }\end{array}$ & $\begin{array}{c}\text { Normal } \\
\text { Normal }\end{array}$ \\
$\begin{array}{l}\text { Short chain acyl-coenzyme A } \\
\text { dehydrogenase }\end{array}$ & $\downarrow \downarrow$ & Normal & $?$ \\
$\begin{array}{l}\text { Medium chain acyl-coenzyme } \\
\text { A dehydrogenase }\end{array}$ & presumed $\downarrow \downarrow$ & $\downarrow$ or normal & $?$ \\
$\begin{array}{l}\text { Long chain acyl-coenzyme A } \\
\text { dehydrogenase }\end{array}$ & presumed $\downarrow \downarrow$ & $\downarrow \downarrow$ & $?$ \\
\hline
\end{tabular}

*Excluding two cases of medium chain acyl-coenzyme A dehydrogenase deficiency.

\section{References}

1 Sinclair-Smith CC, Dinsdale F, Emery JL. Evidence of duration and type of illness in children found unexpectedly dead. Arch Dis Child 1976;51:424-9.

Reye RDK, Morgan G, Baral J. Encephalopathy and fatty degent viscera: a disease entity in childhood. Lancet 1963;ii:749-52.

( Grune and Stratton, 1979:217-37.

4 Delong GR, Glick TH. Encephalopathy of Reye's syndrome: a review of pathogenetic hypotheses. Pediatrics 1982;69:53-63.

Brandt NJ. Symptoms and signs in organic acidurias. Fournal of Inherited Metabolic Disease 1984;7(suppl 1):23-7.

6 Bellman MH, Hall SM. Aetiology of Reye's syndrome. Arch Dis Child 1983; 58:670-2.

7 Mowat AP. Reye's syndrome: 20 years on. Br Med 7 1983;286:1999-2001.

Bove KE, McAdams AJ, Partin JC, Partin JS, Hug G, Schubert WK. The hepatic lesion in Reye's syndrome. Gastroenterology 1975;69:685-97.

Mitchell RA, Ram ML, Arcinue EL, Chang CH. Comparison of cytosolic and mitochondrial hepatic enzyme alterations in Reye's syndrome. Pediatr Res $1980 ; 14: 1216-2$

10 Corey L, Rubin RJ, Bregman D, Gregg MB. Diagnostic criteria for influenza B-associated Reye's syndrome. Clinical vs pathologic criteria. Pediatrics 1977

11 Hall S, Bellman MH. Reye's syndrome in the British Isles BPA/CDSC surveillance scheme. Communicable Disease Report 1983;39:3-6.

12 Howat AJ, Bennett MJ, Variend S, Shaw L. Deficiency of medium chain fatty cylcoenzyme A dehydrogenase presenting as the sudden infant death syndrome $\mathrm{Br} M$ Med 7 1984;288:976.

13 Filipe MI, Lake BD, eds. Histochemistry in pathology. Edinburgh, London Melbourne, New York: Churchill Livingstone, 1983:318-32.

14 Shaw L, Engel PC. The purification and properties of ox liver short-chain

15 Stanley CA, Hale DE, Coates PM, et al. Medium-chain acyl-CoA dehydrogenase deficies.cy in children with non-ketotic hypoglycemia and low carnitine levels. Pediatr Res 1983;17:877-84.

16 Duran M, De Klerk JBC, Wadman SK, Bruinvis L, Ketting D. The differential diagnosis of dicarboxylic aciduria. Fournal of Inherited Metabolic Disease 1984; (suppl 1):48-51.

17 Peterson DR. Epidemiology of the sudden infant death syndrome: problems, progress and prospects. A review. In: Tildon JT, Roeder LM, Steinschneider A, eds. Sudden infant death syndrome. New York, London: Academic Press, 1983:89-97.

18 Sherlock $S$. Acute fatty liver of pregnancy and the microvesicular fat diseases.

Gut 1983;24:265-9.
Sherratt HSA, Veitch RK. Animal models for dicarboxylic aciduria. fournal of Inherited Metabolic Disease 1984;7(suppl 1):52-6.

20 Bergman AB, Beckwith JB, Ray CG. Proceedings of the second international conference on cause of sudden death in infants. Seattle: University of $W$ ashington

(Accepted 14 March 1985)

\title{
Changes in incidence and prognosis of ischaemic heart disease in Finland: a record linkage study of data on death certificates and hospital records for 1972 and 1981
}

\author{
MARKKU KOSKENVUO, JAAKKO KAPRIO, HEIMO LANGINVAINIO, MATTI ROMO, \\ PEKKA PULKKINEN
}

\begin{abstract}
The components of the decline in mortality from ischaemic heart disease in Finland were studied by analysing the changes in incidence and prognosis between 1972 and 1981. Using personal identification numbers, hospital discharge records and death certificates were linked for all men and women aged 40-64. During this period mortality decreased $15.9 \%$ in men and $23.5 \%$ in women, incidence $14.2 \%$ in men and $19 \cdot 3 \%$ in women, being greatest among 40-49 year olds living in urban areas, and case fatality
\end{abstract}

Department of Public Health Science, University of Helsinki, 00290 Helsinki 29, Finland

MARKKU KOSKENVUO, MD, assistant professor of public health JAAKKO KAPRIO, MD, research assistant of the Finnish Academy HEIMO LANGINVAINIO, $M D$, assistant of public health

MATTI ROMO, MD, docent of public health

PEKKA PULKKINEN, BSC, systems analyst

Correspondence to: Dr Koskenvuo.
$7.3 \%$ in men and $10.3 \%$ in women, owing primarily to a decrease in patients dying of ischaemic heart disease without being admitted to hospital; survival was also better among patients admitted to hospital.

Factors explaining these changes remain unknown because data on risk factors and factors influencing prognosis are limited and largely ecological.

\section{Introduction}

The epidemic of ischaemic heart disease in industrialised countries has been waning in some countries while waxing in others over the past $10-15$ years. ${ }^{1-7}$ Ischaemic heart disease mortality has been declining in Finland since $1969-70$ by a yearly $2 \% \cdot{ }^{8}{ }^{9}$ This decline may be due either to factors improving the prognosis of incident cases or to a decline in incidence of the disease. Because data on changes in incidence of ischaemic heart disease world wide are few we examined data on admission to hospital for and mortality from ischaemic heart disease in Finland for 1972 and 1981 to assess relative changes in mortality, survival, and incidence. 


\section{Subjects and methods}

We based our study on a computer file of the death certificates of everybody aged 40-64 dying of ischaemic heart disease (International Classification of Diseases (ICD) codes 410-414) in Finland in 1972 or 1981 and a computer file of records of all hospital discharges during 1972 and 1981 for the same age group. ${ }^{10} \mathrm{We}$ also used a computer file of all death certificates for 1973 and 1982 to calculate one year survival rates. The hospital records of all patients with an acute myocardial infarction or chronic coronary heart disease (ICD codes 410 and 412) as the principal diagnosis were included. Hospital discharge data were gathered from all general hospitals. ${ }^{11}$ Incidence of ischaemic heart disease (first admission to hospital for or death from) was calculated by combining the death certificates and hospital records for the year under consideration. Altogether 3284 men and 768 women in the age group (age at first ischaemic heart disease event in 1972 or 1981) 40-64 years died from ischaemic heart disease during 1972. The corresponding figures for 1981 were 2818 men and 577 women.

The reference population was based on the 1972 and 1981 mid-year populations broken down by sex, five year age groups, and urban versus rural residence. People living abroad were excluded from the reference population when calculating rates of admission to hospital. Analysis was carried out by computing direct standardised rates on incidence, mortality, and one year ( 365 days) case fatality using as the standard population the combined 1972 and 1981 populations.

Recording of personal identification numbers was not complete on all hospital records. The proportion of missing or incorrect identification numbers was $10.9 \%$ in 1972 and $5.7 \%$ in 1981 among 40-64 year olds, varying by sex and by province from $3 \cdot 3 \%$ to $15 \cdot 4 \%$. This source of error was taken into account by calculating adjusted case fatality figures under the assumption that the survival of the patients with incomplete identification number was similar to that of patients with complete data. The adjustment was performed in each sex, five year age group, and province combination. Place of residence was missing from $0.1 \%$ of death certificates and $1.2 \%$ of hospital records. The urban or rural state of communities was coded and analysed according to data for 1981 .

\section{Results}

Tables I and II show our findings. Changes in incidence, case fatality, and mortality varied greatly by age and sex. We also analysed absolute change $(\%)$ in one year case fatality among patients admitted to hospital for ischaemic heart disease (table III).

\section{Discussion}

Computer linkage of death certificates and hospital records became possible for the first time in 1972, when the personal identification number was included in both data sets. The reliability of recordings of ischaemic heart disease as the cause of death on death certificates was satisfactory for epidemiological purposes. ${ }^{12}{ }^{13}$ The reliability of ischaemic heart disease as a hospital discharge diagnosis has been studied systematically in Finland and found to be satisfactory for epidemiological purposes. ${ }^{13}$ In a sample of hospitals about $15 \%$ of discharge records on ischaemic heart disease were missing. ${ }^{13}$ The probable decrease in the proportion of missing records during 1972-81 would offset the real decline in incidence. The results for changes in incidence were probably therefore a slight underestimate. Date of birth was nearly always recorded but not the personal identification number $(10.9 \%$ missing in $1972,5.7 \%$ in 1978). The effect of this source of error was adjusted for as described above. On the other hand, changes in diagnostic criteria for ischaemic heart disease in hospital records or changes in incidence of unrecognised myocardial infarctions ${ }^{14}$ could not be assessed.

The causes of the decrease in ischaemic heart disease mortality have been debated, ${ }^{1-4} 8{ }^{15-18}$ but definite evidence has not been found. Possible explanations have been linked to changes in diet, physical activity, and smoking as well as in medical care (improved intensive care, new antiarrhythmic drugs, and better control of hypertensive patients). In Finland the decrease in mortality seems to be associated with both decreased incidence and better survival.
TABLE I-Relative change (\%) in incidence, case fatality, and mortality for ischaemic heart disease (IHD) in Finland in 1972 and 1981 among men and women aged 40-64 years

\begin{tabular}{|c|c|c|c|c|c|c|c|c|}
\hline \multirow{2}{*}{$\begin{array}{l}\text { Age } \\
\text { (years) }\end{array}$} & \multicolumn{2}{|c|}{ Incidence } & \multicolumn{2}{|c|}{$\begin{array}{l}\text { Case fatality } \\
\text { (first year) }\end{array}$} & \multicolumn{2}{|c|}{ Mortality } & \multicolumn{2}{|c|}{$\begin{array}{c}\text { No of deaths } \\
\text { due to IHD in } \\
1981\end{array}$} \\
\hline & $\overline{\text { Men }}$ & Women & $\overline{\text { Men }}$ & $\overline{\text { Women }}$ & Men & Women & Men & Women \\
\hline $\begin{array}{l}40-44 \\
45-49 \\
50-54 \\
55-59 \\
60-64\end{array}$ & $\begin{array}{r}-33.7 \\
-33.5 \\
-16.3 \\
-3.1 \\
-2.0\end{array}$ & $\begin{array}{r}-40.4 \\
-42.3 \\
-26.5 \\
-23.3 \\
-6.4\end{array}$ & $\begin{array}{r}-22.2 \\
+0.6 \\
-9.9 \\
-4.3 \\
-4.1\end{array}$ & $\begin{array}{r}-33.1 \\
+40.5 \\
-7.3 \\
-11.3 \\
-12.1\end{array}$ & $\begin{array}{r}-49.1 \\
-29.1 \\
-25.5 \\
-10.3 \\
-5.5\end{array}$ & $\begin{array}{r}-63.7 \\
-8.9 \\
-33.1 \\
-28.7 \\
-16.6\end{array}$ & $\begin{array}{r}120 \\
274 \\
548 \\
861 \\
1015\end{array}$ & $\begin{array}{r}9 \\
23 \\
73 \\
143 \\
329\end{array}$ \\
\hline $\begin{array}{l}\text { Age adju } \\
\text { total }\end{array}$ & $-14 \cdot 2$ & $-19 \cdot 3$ & $-7 \cdot 3$ & $-10 \cdot 3$ & $-15 \cdot 9$ & -23.5 & 2818 & 577 \\
\hline
\end{tabular}

TABLE II-Relative change (\%) in incidence, case fatality, and mortality for ischaemic heart disease in 1972 and 1981 in Finland among men and women aged 40-64 years. (Absolute figures in 1981 in parentheses)

\begin{tabular}{|c|c|c|}
\hline & Men & Women \\
\hline & \multicolumn{2}{|c|}{ Incidence* } \\
\hline \multirow[t]{2}{*}{$\begin{array}{l}\text { Urban areas } \\
\text { Rural areas } \\
\text { Whole country }\end{array}$} & $\begin{array}{r}-19 \cdot 1(1270) \\
-8 \cdot 5(1338) \\
-14 \cdot 2(1303)\end{array}$ & $\begin{array}{l}-21.9(296) \\
-16.4(314) \\
-19.3(305)\end{array}$ \\
\hline & \multicolumn{2}{|c|}{ Case fatality (first year) $\dagger$} \\
\hline \multirow[t]{2}{*}{$\begin{array}{l}\text { Urban areas } \\
\text { Rural areas } \\
\text { Whole country }\end{array}$} & $\begin{array}{l}-5.6(33.4) \\
-8.9(34.9) \\
-7.3(34.1)\end{array}$ & $\begin{array}{r}-9.6(21.6) \\
-11.3(23.6) \\
-10.3(22.6)\end{array}$ \\
\hline & \multicolumn{2}{|c|}{ Mortality ${ }^{*}$} \\
\hline $\begin{array}{l}\text { Urban areas } \\
\text { Rural areas } \\
\text { Whole country }\end{array}$ & $\begin{array}{l}-18.6(470) \\
-12.9(485) \\
-15.9(477)\end{array}$ & $\begin{array}{l}-23.8(75) \\
-23.3(85) \\
-23.5(80)\end{array}$ \\
\hline
\end{tabular}

*Number/100 000 people/year.

+Proportion of cases leading to death in first year (\%)

TABLE III-Absolute change (\%) in fatality due to ischaemic heart disease among all incident cases and among patients admitted to hospital aged 40-64 in 1972 and 1981 by sex. (Absolute percentage of one year fatality in 1981 in parentheses)

\begin{tabular}{|c|c|c|}
\hline & Men & Women \\
\hline & \multicolumn{2}{|c|}{ Patients admitted to hospital } \\
\hline \multirow[t]{2}{*}{$\begin{array}{l}\text { Urban areas } \\
\text { Rural areas } \\
\text { Whole country }\end{array}$} & $\begin{array}{l}-0.2(14.2) \\
-0.9(13.8) \\
-0.5(14.0)\end{array}$ & $\begin{array}{l}+0.6(8.7) \\
-1.8(8.6) \\
-0.5(8.7)\end{array}$ \\
\hline & \multicolumn{2}{|c|}{ All incident cases } \\
\hline $\begin{array}{l}\text { Urban areas } \\
\text { Rural areas } \\
\text { Whole country }\end{array}$ & $\begin{array}{l}-2.0(33 \cdot 4) \\
-3.4(34 \cdot 9) \\
-2 \cdot 7(34 \cdot 1)\end{array}$ & $\begin{array}{l}-2.3(21 \cdot 6) \\
-3.0(23 \cdot 6) \\
-2.6(22 \cdot 6)\end{array}$ \\
\hline
\end{tabular}

Changes in health behaviour should be found among men and women born in 1920-30. Reliable data on such changes in the population are not available for Finland. There are some ecological data on diet and smoking, ${ }^{8}$ but it is difficult to draw conclusions from ecological exposure data to individual end points. Between 1972 and 1981 smoking increased slightly among middle aged women and decreased slightly among men. The proportion of animal fats in the diet has decreased. ${ }^{8}$ Changes in physical activity have not been studied systematically, but physical activity has decreased at work and increased at leisure.

Changes in risk factors for coronary heart disease between 1972 and 1977 have been studied in the North Karelia project in a sample of the population of two counties in eastern Finland, representing about $9 \%$ of the Finnish population. ${ }^{1920}$ This study showed, for 1972 and 1977: a slight decrease in smoking among men and a slight increase among women; a slight decrease in mean serum cholesterol concentration; and a decrease in systolic and diastolic blood pressure, especially among women.

The Public Health Act of 1972 has improved primary health care, particularly in rural areas. Treatment of high blood pressure has improved over the whole country. The age standardised 
proportion of drug treatment of hypertension among 45-64 year olds increased during $1972-81$ from $3.5 \%$ to $14.6 \%$ for men and from $7.8 \%$ to $17.9 \%$ for women as reported by the Social Insurance Institution. ${ }^{21}{ }^{22}$ The better control of high blood pressure may be associated with the decrease in case fatality.

When causes of changes in incidence are considered the basic question is the change in prevalence and degree of coronary atherosclerosis. ${ }^{23}{ }^{24}$ In Finland the necropsy rate has been quite high during the past 30 years, ${ }^{10}$ but there has been no systematic recording of the prevalence of coronary atherosclerosis. The effect of various factors on changes in incidence of ischaemic heart disease, however, remains open to debate as long as individual data are not available.

This study was supported by a grant from the Finnish Heart Association.

\section{References}

1 Gillum RF, Blackburn H, Feinleib M. Current strategies for explaining the de2 Levy RI. Declining mortality in coronary heart disease. Arteriosclerosis $1981 ; 1$ :

3 Feinleib $M$, Rifkind BM. Changing patterns of cardiovascular disease mortality in the United States. Isr $\mathcal{F}$ Med Sci 1982;18:1098-105.

4 Marmot MG, Booth M, Beral V. International trends in heart disease mortality. Atherosclerosis Reviews 1982;9:19-27.

5 Pisa $Z$, Uemura $K$. Trends of mortality from ischaemic heart disease and other cardiovascular diseases in 27 countries, 1968-1977. World Health Stat $\mathcal{Q}$ $1982 ; 35: 11-47$ dint

6 Alfredsson $\mathrm{L}$, Ahlblom A. Increasing incidence and mortality from myocardial

7 Welin L, Larsson B, Svãrdudd K, et al. Why is the incidence of ischaemic heart disease in Sweden increasing ? Study of men born in 1913 and 1923. Lancet $1983 ; \mathrm{i}: 1087-9$.

8 Pyörälä $\mathrm{K}$, Valkonen $\mathrm{T}$. The high ischaemic heart disease mortality in Finland. International comparisons, regional differences, trends and possible causes. In : Skandia international symposia. Medical aspects of mortality statistics. Stockholm: Almqvist and Wicksell International, 1981:37-57.

9 Salonen JT, Puska P, Kottke TE, et al. Decline in mortality from coronary heart disease in Finland from 1969 to 1979. Br Med f 1983;286:1857-60.

10 Romo M, Koskenvuo M, Kaprio J, et al. Incidence and prognosis of ischaemic $355-60$.

11 National Board of Health. Health services. Helsinki: National Board of Health, 1979. (Official statistics of Finland XI:75.)

12 Penttilä A, Ahonen A. Arteriosclerotic and other degenerative heart diseases in Finland. II. A death certificate study of the examination of death from degenerative heart diseases. Scand F Soc Med 1975;3:69.

13 Heliövaara M, Reunanen A, Aromaa A, et al. Validity of hospital discharge data in a prospective study on stroke and myocardial infarction. Acta Med Scand

14 Kannel WB, Abbott RD. Incidence and prognosis of unrecognized myocardial infarction: an update of the Framingham study. $N$ Engl $\mathcal{F}$ Med 1984;311 1144-7.

, eook F, Hashimoto B, et al. Evidence that hospital care for acute

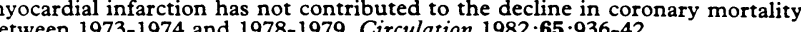
16 Feinleib M. Risk assessment, environmental fion 1982;65:936-42. fournal of the American College of Toxicology 1983;2:91-104.

$17 \mathrm{Kannel}$ WB, Thom TJ. Declining cardiovascular mortality. Circulation 1984;70:

18 Stewart AW, Beaglehole R, Fraser GE, Sharpe DN. Trends in survival after myocardial infarction in New Zealand, 1974-1981. Lancet 1984; ii:444-6.

19 National Public Health Laboratory of Finland. Community control of cardiovascular diseases. The North Karelia project. Copenhagen: WHO, 1981.

20 Puska P, Salonen JT, Nissinen A, et al. Change in risk factors for coronary heart disease during 10 years of a community intervention programme (North Karelia project). Br Med $\mathcal{O}$ 1983;287:1840-4.

21 Social Insurance Institution. Kansaneläkelaitoksen tilastollisia vuosikatsauksia 1972. Helsinki: Kansaneläkelaitos, 1974 . (Sairaustilastot T3:1C.)

22 Social Insurance Institution. Kansaneläkelaitoksen tilastollisia vuosikatsauksia 1981. Helsinki: Kansaneläkelaitos, 1982. (Sairaustilastot T3:10C.)

23 Strong JP, Guzman MA. Decrease in coronary atherosclerosis in New Orleans. Lab Invest 1980;43:297-301.

24 Elveback L, Lie JT. Continued high incidence of coronary artery disease at autops

(Accepted 14 March 1985)

\title{
Pulmonary haemorrhage complicating Wegener's granulomatosis and microscopic polyarteritis
}

\author{
S J HAWORTH, C O S SAVAGE, D CARR, J M B HUGHES, A J REES
}

\begin{abstract}
The incidence and characteristics of pulmonary haemorrhage in a series of 89 patients with systemic vasculitis were analysed. Pulmonary haemorrhage occurred in 32 of these patients and was associated with haemoptysis in all 32, alveolar shadowing in the chest radiograph in 28 , and a significantly raised transfer coefficient in 30 . Pulmonary haemorrhage usually resolved with treatment by immunosuppressive drugs but was the cause of death in 11 patients. In contrast with patients with antibasement membrane antibodies there was no correlation between pulmonary haemorrhage and cigarette smoking.

Pulmonary haemorrhage is a cause of serious morbidity in patients with systemic vasculitis.

\footnotetext{
Royal Postgraduate Medical School, Hammersmith Hospital, London W12 0HS

S J HAWORTH, MB, MRCP, research fellow, renal unit C O S SAVAGE, MB, MRCP, research fellow, renal unit $D$ CARR, MD, FRCR, senior lecturer in diagnostic radiology

J M B HUGHES, DM, FRCP, senior lecturer in medicine

A J REES, MSC, FRCP, consultant nephrologist and honorary senior lecturer

Correspondence to: Dr S J Haworth, MRC Clinical Immunology Research Group, Renal Unit, Department of Medicine, Royal Postgraduate Medical School, Hammersmith Hospital, London W12 0HS.
}

\section{Introduction}

The association of pulmonary haemorrhage with necrotising glomerulonephritis is usually called Goodpasture's syndrome. Many patients with Goodpasture's syndrome have autoantibodies to glomerular and alveolar basement membrane antigens $^{1}$ and the term is sometimes restricted to these. Nevertheless, glomerulonephritis and pulmonary haemorrhage coexist in other diseases, such as Wegener's granulomatosis, ${ }^{2}$ microscopic polyarteritis, ${ }^{3}$ systemic lupus erythematosus, and, rarely, mixed essential cryoglobulinaemia, HenochSchönlein purpura, rheumatoid vasculitis, and mixed connective tissue disease. ${ }^{5}$

Descriptions of pulmonary haemorrhage and nephritis in patients without antiglomerular basement membrane antibody disease have generally been restricted to individual reports of severe, often fatal cases and the overall prevalence has not been documented reliably. This is partly because of the rarity of the underlying diseases and also because the diagnosis of pulmonary haemorrhage is usually circumstantial. For example, haemoptysis does not differentiate bleeding from the large airways, commonly found in Wegener's granulomatosis, and alveolar haemorrhage; haemoptysis may be trivial ${ }^{6}$; radiological features are not specific and may even be absent ${ }^{7}$; and traditional confirmatory investigations such as lung biopsy, bronchoscopy with lavage, or radioisotope techniques are cumbersome or invasive. The diagnosis has been simplified considerably by the observation that the diffusing capacity for carbon monoxide, especially 